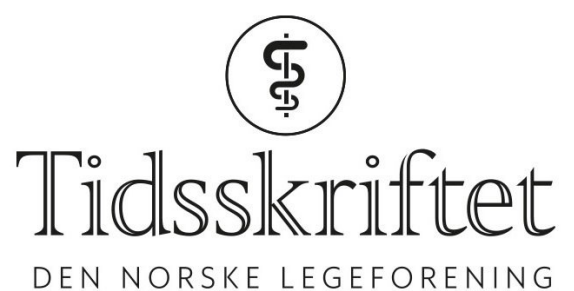

DEN NORSKE LEGEFORENING

\title{
Når kan helsepersonell lese i pasientjournalen?
}

DEBATT

\section{HAAKON LINDEKLEIV}

E-post: haakon.lindekleiv@unn.no

Haakon Lindekleiv (f. 1982) er medisinsk fagsjef ved Universitetssykehuset Nord-Norge. Forfatter har fylt ut ICMJE-skjemaet og oppgir ingen interessekonflikter.

Å lese om pasientens forløp er viktig i læringsøyemed. I dag åpner lovverket i liten grad opp for at helsepersonell, som har vært involvert i pasientbehandlingen, kan følge med i behandlingsforløpet og få vite endelig diagnose.

Alle innsyn i elektroniske pasientjournaler loggføres, og pasienter har rett til innsyn i denne loggen, jf. pasientjournalloven $\S 18$, første ledd (1). I dag har mange pasienter elektronisk tilgang til egen journal og innsynslogg (2).Ved Universitetssykehuset NordNorge har vi erfart at flere pasienter enn tidligere ønsker opplysninger om hvorfor helsepersonell har lest i journalen.

Mange ansatte i helsevesenet ønsker å lese i journalen til pasienter de tidligere har hatt til behandling - for å vite behandlingsforløpet og den endelige diagnosen. Det gjelder blant annet leger som skriver innkomstjournaler i akuttmottaket.

Helsepersonell kan alltid gå inn i en journal dersom pasienten gir samtykke. Det finnes imidlertid mange situasjoner der helsepersonell ikke kan få et gyldig samtykke eller der det er etisk vanskelig å spørre om samtykke. Dette gjelder blant annet i akuttsituasjoner og der pasienter har redusert bevissthet.

Innsyn i pasientjournal for egen læring, uten at det er innhentet samtykke, er regulert av helsepersonelloven § 29 c (3). Denne lød før lovendring 1.1.2015 slik: «Med mindre pasienten motsetter seg det, kan taushetsbelagte opplysninger etter særskilt anmodning gis til annet helsepersonell som tidligere har ytt helsehjelp til pasienten i et konkret behandlingsforløp, dersom utleveringen er begrunnet i lærings- og kvalitetssikringshensyn. Utlevering etter første ledd skal begrenses til de opplysninger som er nødvendige og relevante for formålet. I pasientens journal skal det dokumenteres hvem opplysninger har blitt utlevert til og hvilke opplysninger som har blitt utlevert, jf. § 40.»

Helsepersonelloven § $29 \mathrm{c}$ ble endret 1.1.2015. Begrunnelsen for endringen var blant annet å gjøre det enklere for helsepersonell å få tilgang til pasientopplysninger i læringsøyemed: «Med mindre pasienten motsetter seg det, kan taushetsbelagte opplysninger etter særskilt anmodning gis til annet helsepersonell som tidligere har ytt helsehjelp til pasienten i et konkret behandlingsforløp, for kvalitetssikring av helsehjelpen eller egen læring. Behandlingen av anmodningen kan automatiseres. Helsepersonell kan bare gis de 
opplysninger som er nødvendige og relevante for formålet. I pasientens journal skal det dokumenteres hvem opplysninger har blitt utlevert til og hvilke opplysninger som har blitt utlevert, jf. § 40.»

\section{Tilpasset sykehushverdagen?}

Universitetssykehuset Nord-Norge har vært i kontakt med Helsedirektoratet som i likhet med våre jurister tolker paragrafen slik at helsepersonell ikke selv kan gå inn i journalen, men først må forespørre databehandlingsansvarlig (som kan være nærmeste leder) om innsyn. Databehandlingsansvarlig må deretter vurdere og dokumentere tilgangsrett og hvilke opplysninger som er relevante og nødvendige, og som kan utleveres. Regelverket åpner for at utleveringen av opplysningene til helsepersonell kan foregå ved at personellet selv henter ut opplysningene.

Det er vanskelig å se for seg at nærmeste leder kan utlevere opplysninger slik det er beskrevet av lovgiver. Ansatte i helsetjenesten har mange pasienter, og hver leder har mange underordnede. Volumet av slike forespørsler vil bli for omfangsrikt til at det er praktisk mulig for nærmeste leder å vurdere tilgangsretten og hvilke opplysninger som er nødvendige og relevante å utlevere.

Lovgiver har i endringen av helsepersonelloven § $29 \mathrm{c}$ åpnet opp for at behandlingen av slike forespørsler kan automatiseres. Dette er en god tanke, men de tekniske systemene for dette er ikke tilgjengelige. Regelendringen har derfor ikke hatt praktisk betydning.

\section{For å lære}

Er praksis ved norske sykehus i dag i tråd med regelverket? Mange helsearbeidere følger selv med $\mathrm{i}$ journalen på pasienter de har deltatt $\mathrm{i}$ behandlingen av, også uten at det er dokumentert samtykke for slike innsyn. Det er lite ønskelig å stramme inn denne praksisen. Kunnskap om behandlingsforløp og endelig diagnose er svært viktig for at helsepersonell skal lære og forbedre seg. Problemstillingen gjelder også andre yrkesgrupper enn leger, for eksempel ambulansearbeidere og sykepleiere.

Lovgiver bør revurdere føringene i helsepersonelloven § 29 c, slik at helsepersonell lettere kan lære av pasientforløp de har vært involvert i. I dag åpner lovverket i liten grad opp for at helsepersonell som har vært involvert i pasientbehandlingen, gis anledning til å slå opp $\mathrm{i}$ journal for å følge med i behandlingsforløp og diagnose. Dette begrenser muligheten for helsepersonell til å forbedre seg og er vanskelig å gjennomføre i sykehushverdagen. Disse bekymringene ble også uttrykt i lovforarbeidet (4).

\section{LITTERATUR:}

1. LOV-2014-06-20-42. Lov 20. juni 2014 om Lov om behandling av helseopplysninger ved ytelse av helsehjelp (pasientjournalloven). https://lovdata.no/dokument/NL/lov/2014-o6-2O-42 (29.1.2018).

2. Helsedirektoratet. Rett til innsyn i pasientjournalen din 2016.

https://helsenorge.no/rettigheter/pasientjournal (29.1.2018).

3. LOV-1999-07-02-64. Lov 2. juli 1999 om helsepersonell m.v. (helsepersonelloven). https://lovdata.no/dokument/NL/lov/1999-07-02-64 (29.1.2018).

4. Prop. 72 L (2013-2014). Pasientjournalloven og helseregisterloven. https://www.regjeringen.no/no/dokumenter/prop-72-L-20132014/id756657/ (29.1.2018).

Publisert: 5. mars 2018. Tidsskr Nor Legeforen. DOI: 10.4045/tidsskr.18.0111

(C) Tidsskrift for Den norske legeforening 2020. Lastet ned fra tidsskriftet.no 